\title{
Development and validation of a bioanalytical LC-UV method with solid-phase extraction for determination of valproic acid in saliva
}

\author{
JASMINA TONIC-RIBARSKA ${ }^{1 *}$ \\ ARLINDA HAXHIU ${ }^{2}$ \\ ZORAN STERJEV ${ }^{3}$ \\ GORDANA KITEVA ${ }^{4}$ \\ LJUBICA SUTURKOVA ${ }^{3}$ \\ SUZANA TRAJKOVIC-JOLEVSKA ${ }^{1}$ \\ ${ }^{1}$ Institute of Applied Chemistry and \\ Pharmaceutical Analysis, Faculty of \\ Pharmacy, University »Ss Cyril and \\ Methodius«, Skopje, Macedonia \\ 2 Department of Pharmacy, Medical \\ Sciences Faculty, State University \\ of Tetova, Tetovo, Macedonia \\ ${ }^{3}$ Institute of Pharmaceutical Chemistry \\ Faculty of Pharmacy, University \\ "Ss Cyril and Methodius" \\ Skopje, Macedonia \\ ${ }^{4}$ Clinic of Neurology, Faculty of \\ Medicine, University "Ss Cyril \\ and Methodius", Skopje, Macedonia
}

\begin{abstract}
A bioanalytical HPLC method with UV detection for the determination of the antiepileptic drug valproic acid in human saliva has been developed and validated. Saliva represents an alternative matrix for therapeutic monitoring of antiepileptic drugs due to the increasing interest in free drug concentration. The proposed method involved solid-phase extraction for sample preparation and yielded very good mean recoveries of $99.4 \%$ and $97.9 \%$ for valproic acid and IS, respectively. The calibration function for valproic acid was linear over the concentration range of $1.0-50.0 \mu \mathrm{g} \mathrm{mL}^{-1}\left(R^{2}=0.9989\right)$. Within-run and between-run precision and accuracy were studied at four concentrations and RSDs were less than 7.3 and $2.2 \%$, while accuracy values were higher than 96.8 and $97.5 \%$, respectively. The described method provides sensitivity, linearity, precision, accuracy and is suitable for analyses of valproic acid in saliva samples.
\end{abstract}

Keywords: valproic acid, saliva, solid-phase extraction, high-performance liquid chromatography, validation

Valproic acid (2-propylpentanoic acid) is an anticonvulsant drug, widely used in the treatment of epilepsy, affecting both children and adults $(1,2)$. It is also used to treat bipolar disorder and to prevent migraine headaches (3).

Therapeutic drug monitoring (TDM) of antiepileptic drugs (AEDs) is used in clinical practice to aid the treatment of patients with epilepsy. In order to obtain information

\footnotetext{
* Correspondence; e-mail: jasminatonic@yahoo.com
} 
for TDM, the development of a reliable analytical method for the determination of AEDs in biological fluids is of great importance (4). Serum and plasma represent the matrices of choice for TDM of AEDs. Their concentration can be also measured in saliva, urine, cerebrospinal fluid and tears (5). In the last 30 years, saliva has been advocated as an alternative matrix and the increasing interest in free drug concentration monitoring has provided a renewed impetus in saliva monitoring of antiepileptic drugs (6). The measurement of free drug concentration is desirable but it is difficult to achieve in practice because the processes as equilibrium of dialysis and ultracentrifugation are time-consuming, expensive and require large sample volumes (7). For a highly protein-bound drug, such as VPA ( $\geq 90 \%$, which results in a free fraction of only $10 \%$ ), saliva is the most suitable matrix for measuring the free concentration, because saliva can be expected to behave as a natural ultra filtrate of plasma. It is also an attractive alternative, because saliva collection is noninvasive, painless, simpler, less stressful, does not involve fear and discomfort, and complications of infection and thrombosis. Saliva sampling is especially useful in paediatric, geriatric and patients with disabilities (8).

Several methods involving immunoassay (9), gas-chromatography (10), high-performance liquid chromatography $(11,12)$ and LC-MS/MS (13) have been reported for the determination of valproic acid in biological fluids. According to our knowledge, no HPLC-UV methods for the determination of valproic acid in saliva have been published so far.

The aim of our study was to develop and validate a reliable HPLC-UV detection method for the determination of VPA in saliva using the solid phase extraction procedure for the sample preparation.

\section{EXPERIMENTAL}

\section{Chemicals and reagents}

Valproic acid sodium salt and octanoic acid (internal standard, IS), analytical standards were purchased from Sigma-Aldrich Inc., USA. Methanol (HPLC grade) and acetonitrile (HPLC grade) were purchased from Merck, Germany. Potassium dihydrogen phosphate and phosphoric acid for buffer preparation were of analytical grade and were also obtained from Merck. For all analyses, HPLC grade water purified with a TKA_LAB Reinstwasser system (Niederelbert, Germany) was used. SampliQ OPT cartridges used for sample preparation were procured from Agilent Technologies, USA.

\section{Collection of saliva samples}

Saliva was collected from healthy volunteers (for method validation) and from epileptic patients. Saliva samples were collected at least 2 hours after the intake of the last dose of valproic acid. Patients were instructed to first rinse the mouth thoroughly and repeatedly with water to remove any remnants of food or medication. About five millilitre of nonstimulated liquid clear saliva was collected into collecting tube. Saliva samples were than frozen and stored at $-20{ }^{\circ} \mathrm{C}$ until analysis. 
J. Tonic-Ribarska et al:: Development and validation of a bioanalytical LC-UV method with solid-phase extraction for determination of valproic acid in saliva, Acta Pharm. 62 (2012) 211-220.

Participation of each subject was voluntary and could be cancelled by any individual at any time during the study (according to the Helsinki II declaration). The Ethics Committee at the Faculty of Pharmacy and the Faculty of Medicine, Ss. Cyril and Methodius University - Skopje, approved the research protocol for this study and all volunteers signed the Study Informed Consent form.

\section{Chromatographic conditions}

The assay was performed on an Agilent 1200 series HPLC system (Agilent Technologies) equipped with a vacuum degasser (G1322A Degasser), quaternary pump (G1311A QuatPump), autosampler (G1329A ALS), column compartment (G1316A TCC), diode array detector (G1315D DAD), and ChemStation for LC 3D software for data handling.

Separation was performed on a Zorbax Eclipse XDB C-18 $(150 \times 4.6 \mathrm{~mm} ; 5 \mu \mathrm{m})$ col-

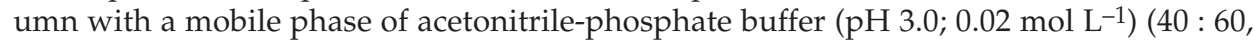
$V / V)$. The analyses were run at a flow rate of $1 \mathrm{~mL} \mathrm{~min}^{-1}$, volume of injection $100 \mu \mathrm{L}$ and temperature $25^{\circ} \mathrm{C}$. Detection was made at $210 \mathrm{~nm}$.

\section{Preparation of standards and quality control samples}

Stock standard solutions of valproic acid $\left(500 \mu \mathrm{g} \mathrm{mL}^{-1}\right)$ and internal standard of octanoic acid $\left(364 \mu \mathrm{g} \mathrm{mL}^{-1}\right)$ were prepared by dissolution in methanol. Working solutions were obtained by serial dilutions of the stock solution of valproic acid with purified water. Stock solutions were stored at $2-8{ }^{\circ} \mathrm{C}$ and were stable for one month.

Seven calibration standards of valproic acid were made by spiking the blank saliva aliquots with an appropriate volume of the working solutions of valproic acid, giving the final concentration of 1.0 to $50.0 \mu \mathrm{g} \mathrm{mL}^{-1}$, containing the IS at a constant concentration of $36.4 \mu \mathrm{g} \mathrm{mL}^{-1}$. Calibration curve was constructed using the ratio of peak areas of valproic acid and octanoic acid as a function of valproic acid concentration.

Four levels of quality control (QC) samples were prepared at concentrations of 1.0 $\mu \mathrm{g} \mathrm{mL} \mathrm{m}^{-1}$ (lower limit of quantitation), $5.0 \mu \mathrm{g} \mathrm{mL}-1$ (low QC sample), $10.0 \mu \mathrm{g} \mathrm{mL}^{-1}$ (medium QC sample) and $20.0 \mu \mathrm{g} \mathrm{mL}^{-1}$ (high QC sample), in the same way as described above for the calibration standards, and stored at $-20^{\circ} \mathrm{C}$ until analysis. The QC samples were used to assess the accuracy and precision of the method.

Each spiked saliva sample was processed as described in sample preparation.

\section{Sample preparation}

Preparation of samples was based on the solid-phase extraction (SPE) as a selective method for sample preparation. Frozen saliva samples collected from healthy volunteers and epileptic patients were allowed to thaw at room temperature before being centrifuged at $3000 \mathrm{rpm}$ for $15 \mathrm{~min}$. This procedure is done in order to overcome the difficulties resulting from the high viscosity of freshly obtained saliva (highly mucous, stringy and sticky consistence). The supernatant from an epileptic patient's saliva was transferred into the Eppendorf tube and spiked with $100 \mu \mathrm{L}$ IS $\left(36.4 \mu \mathrm{g} \mathrm{mL}^{-1}\right)$ and $20 \mu \mathrm{L}$ of $10 \%$ $\mathrm{H}_{3} \mathrm{PO}_{4}$, while the supernatant from blank saliva was previously spiked with valproic acid and IS as described in the section Preparation of standards and quality control samples. The 
mixture was vortex-mixed for $30 \mathrm{~s}$ and loaded into SampliQ OPT cartridges ( $30 \mathrm{mg} / 1 \mathrm{~mL})$ previously conditioned according to the following steps: a) conditioning with $1 \mathrm{~mL}$ methanol; b) equilibration with $1 \mathrm{~mL}$ water; c) loading of $1 \mathrm{~mL}$ saliva sample; d) washing twice with $1 \mathrm{~mL}$ water and $1 \mathrm{~mL} 10 \%$ methanol; e) elution with $200 \mu \mathrm{L} 90 \%$ methanol. The eluate was transferred to microvials and the autosampler was programmed to inject $100 \mu \mathrm{L}$ into the HPLC system.

\section{Bioanalytical method validation}

Method validation was conducted according to the Guideline on Validation of Bioanalytical Methods of the European Medicines Agency (14).

Selectivity. - Selectivity was assessed by comparing the chromatograms of blank saliva samples from six sources and those obtained from a saliva sample spiked with analyte(s) of interest and internal standard.

Linearity and range. - Prior to validation of the bioanalytical method, the concentration range should be justified based on scientific information. The range should be covered by the calibration line range, defined by the lower limit of quantitation (LLOQ) and the upper limit of quantitation (ULOQ).

A minimum of six calibration concentration levels should be used, excluding the blank sample (processed matrix sample without analyte and without IS) and a zero sample (processed matrix with IS). The acceptable criterion for each standard concentration was $\pm 15 \%$ of the nominal value, except for the LLOQ which was $\pm 20 \%$.

Accuracy and precision. - Accuracy and precision were assessed on samples spiked with known amounts of the analyte, the quality control samples (QC samples). Accuracy and precision were evaluated for the values of the QC samples obtained within a single run (the within-run) and in different runs (the between-run). Within-run accuracy and precision were determined at least five samples per concentration level on $L L O Q$, low, medium and high QC samples in a single run. Between-run accuracy and precision were assessed by five determinations per concentration per run on $L L O Q$, low, medium and high QC samples from three runs analysed on at least two different days.

Recovery. - Recovery describes the extraction efficiency of the analytical process. Recovery was calculated by comparing the peak areas of analytes obtained from the SPE processed blank saliva sample previously spiked with analytes $v s$. peak areas obtained from an SPE processed blank saliva sample, and then spiked with analytes, representing $100 \%$ recovery (15).

\section{Stability}

Stability test was performed on three replicates of low and high QC samples after $24 \mathrm{~h}$ at room temperature (short-term stability), after three freeze-thaw cycles, autosampler stability for $10 \mathrm{~h}$ and on samples stored for 30 days at $-20^{\circ} \mathrm{C}$ (long-term stability). 
J. Tonic-Ribarska et al.: Development and validation of a bioanalytical LC-UV method with solid-phase extraction for determination of valproic acid in saliva, Acta Pharm. 62 (2012) 211-220.

\section{RESULTS AND DISCUSSION}

\section{Optimisation of the SPE procedure and development of the RP HPLC-UV method}

During the optimization of the chromatographic conditions, different mobile phases (different $\mathrm{pH}$ values of the buffer, and also different organic to aqueous phase ratios) were evaluated. The best results of good separation of valproic acid and IS were obtained with the mixture of acetonitrile-phosphate buffer $\mathrm{pH} 3.0(40: 60, V / V)$ with the retention times of valproic acid and octanoic acid of 9.8 and $12.4 \mathrm{~min}$, respectively.

During the solid phase extraction procedure, two different types of SPE columns (SampliQ OPT and SampliQ C18 cartridges) and different steps of washing and elution were evaluated. At first, elution with $1 \mathrm{~mL}$ acetonitrile was tested; valproic acid was completely retained by the cartridge. Similar results, with low recovery, were obtained using pure methanol or an acetonitrile-methanol $(50: 50, V / V)$ mixture. The best results for recovery of $99.4 \%$ and $97.9 \%$ for valproic acid and IS, respectively, were obtained using Agilent SampliQ OPT cartridges and the SPE procedure is described in the sample preparation section.

\section{Validation}

Selectivity. - The chromathograms for blank saliva, blank saliva spiked with valproic acid and octanoic acid are presented in Fig. 1. No interfering peaks were observed at the retention times of analyte or IS.

Linearity. - The calibration line was constructed with seven calibration standards within the range of $1.0-50.0 \mu \mathrm{g} \mathrm{mL}-1$, including $L L O Q$. Coefficient of determination $R^{2}$ was 0.9989 and the $L L O Q$ was $1 \mu \mathrm{g} \mathrm{mL}^{-1}$.

Table I. Accuracy and precision of valproic acid in human saliva

\begin{tabular}{ccccc}
\hline & $\begin{array}{c}\text { Nominal concen- } \\
\text { tration }\left(\mu \mathrm{g} \mathrm{mL}^{-1}\right)\end{array}$ & $\begin{array}{c}\text { Found concen- } \\
\text { tration }(\mu \mathrm{g} \mathrm{mL})^{\mathrm{a}}\end{array}$ & $\begin{array}{c}\text { Accuracy } \\
(\%)\end{array}$ & $\begin{array}{c}\text { Precision } \\
(\mathrm{RSD}, \%)\end{array}$ \\
\hline Within-run & 1.00 & $1.04 \pm 0.08$ & 104.3 & 7.3 \\
assay $(n=5)$ & 5.00 & $4.84 \pm 0.13$ & 96.8 & 2.7 \\
& 10.00 & $9.96 \pm 0.08$ & 99.7 & 0.8 \\
Between-run & 20.00 & $19.84 \pm 0.26$ & 99.2 & 1.3 \\
assays $(n=30)$ & 1.00 & $0.99 \pm 0.02$ & 99.4 & 2.2 \\
& 5.00 & $4.88 \pm 0.04$ & 97.5 & 0.7 \\
& 10.00 & $10.04 \pm 0.10$ & 100.4 & 1.0 \\
\hline
\end{tabular}

a Mean \pm SD. 
a)

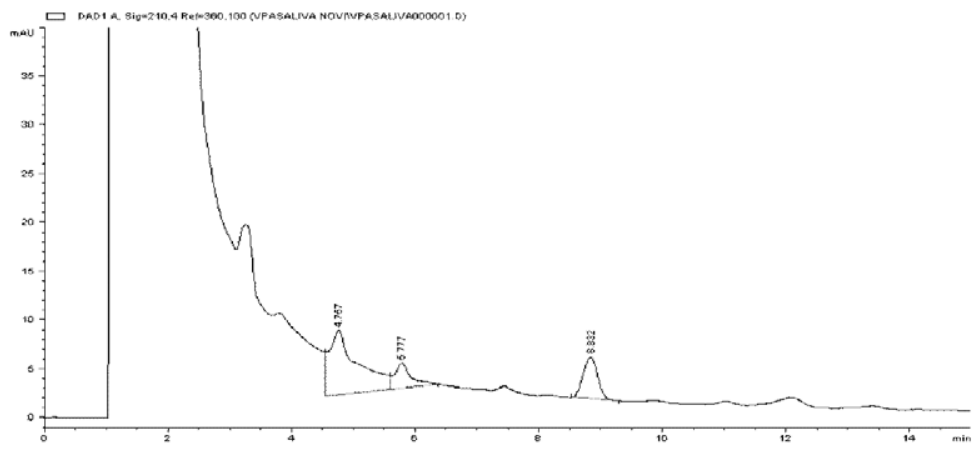

b)

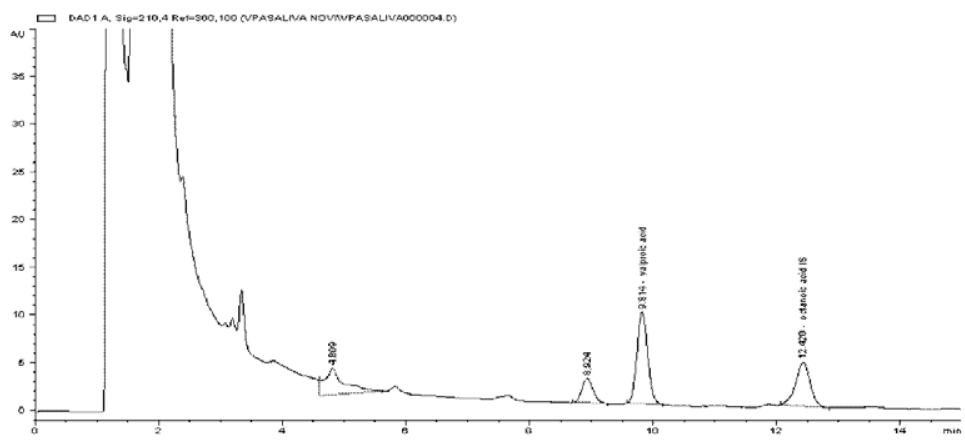

c)

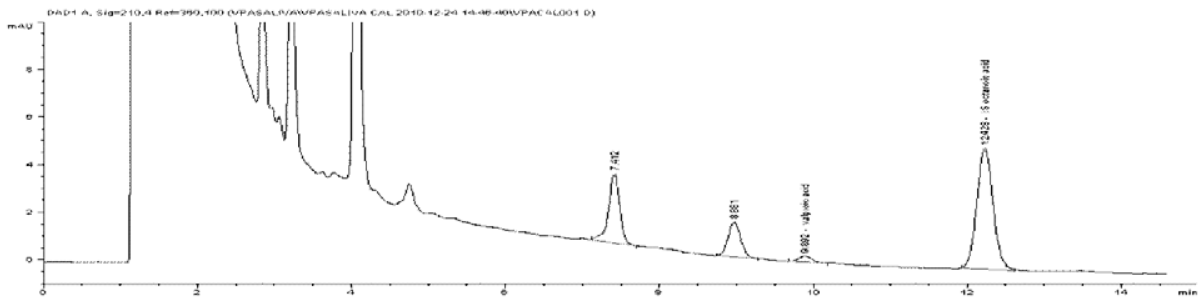

d)

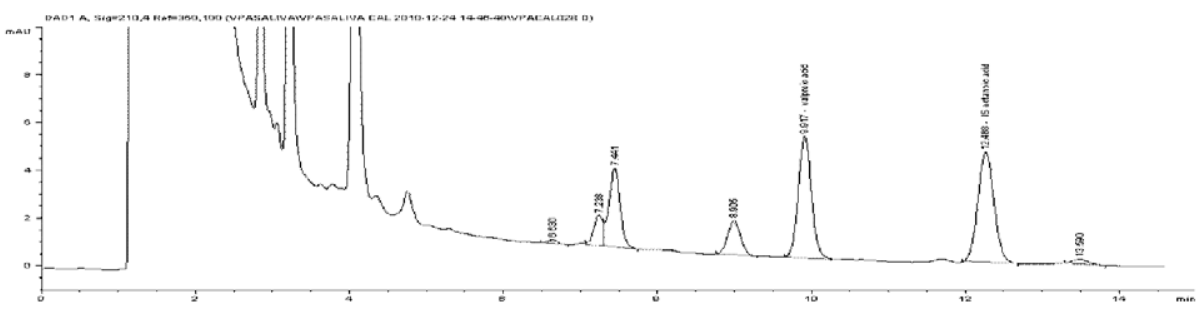

Fig. 1. RP-HPLC chromatograms obtained from: a) blank saliva (drug free saliva), b) blank saliva spiked with valproic acid $\left(50 \mu \mathrm{g} \mathrm{mL}^{-1}\right)$ and octanoic acid $\left(36.2 \mu \mathrm{g} \mathrm{mL}^{-1}\right)$, c) blank saliva spiked with valproic acid at $L L O Q$ level $\left(1.0 \mu \mathrm{g} \mathrm{mL}^{-1}\right)$ and octanoic acid $\left(36.2 \mu \mathrm{g} \mathrm{mL}^{-1}\right)$, d) blank saliva spiked with valproic acid at high QC level $\left(20 \mu \mathrm{g} \mathrm{mL}^{-1}\right)$ and octanoic acid $\left(36.2 \mu \mathrm{g} \mathrm{mL}^{-1}\right)$, after the SPE procedure. Unnamed peaks are the endogenous components of saliva. 
J. Tonic-Ribarska et al.: Development and validation of a bioanalytical LC-UV method with solid-phase extraction for determination of valproic acid in saliva, Acta Pharm. 62 (2012) 211-220.

Accuracy and precision. - The within-run and between-run accuracy and precision are shown in Table I. Within-run assay precision ranged from 0.8 to $7.3 \%$, while within-run assay accuracy ranged from 96.8 to $104.3 \%$. The between-run precision and accuracy ranged from 0.7 to $2.2 \%$ and 97.5 to $100.4 \%$, respectively. The chromatograms of quality control samples at two concentration levels of valproic acid (LLOQ and high QC samples) are shown in Figure 1.

Recovery. - The recoveries of valproic acid at four concentration levels (1.0, 5.0, 10.0 and $20.0 \mu \mathrm{g} \mathrm{mL}^{-1}$ ) were in the range $96.8-99.4 \%$, and the recovery of IS was $97.9 \%$. These results indicate good recoveries for valproic acid and IS, which means that the proposed SPE procedure could be applied to the determination of saliva valproic acid in epileptic patients.

\section{Stability}

Stability experiments were performed by evaluating the stability of valproic acid and octanoic acid stock solutions and saliva samples under different conditions. Stock solutions of valproic acid and IS were stable at room temperature for $24 \mathrm{~h}$ (accuracy: 99.3 and $99.7 \%$, respectively) and at $2-8{ }^{\circ} \mathrm{C}$ for 30 days (accuracy: 100.5 and $99.8 \%$, respectively). It was shown that the human saliva samples spiked with valproic acid were stable after three freeze-thaw cycles, after $12 \mathrm{~h}$ in autosampler and at room temperature for $24 \mathrm{~h}$. The study indicated that the saliva samples could be stored at $-20{ }^{\circ} \mathrm{C}$ for 30 days. The respective VPA concentrations ranged from 92.2 to $104.9 \%$. The results are presented in Table II.

Table II. Stability of valproic acid in saliva under various conditions ${ }^{a}$

\begin{tabular}{lcc}
\hline $\begin{array}{l}\text { Initaial concentration } \\
t=0 \text { min }\left(\mu \mathrm{g} \mathrm{mL}^{-1}\right)\end{array}$ & $\begin{array}{c}\text { Measured concentration } \\
\left(\mu \mathrm{gL}^{-1}\right)\end{array}$ & Precision (RSD, \%) \\
\hline $\begin{array}{l}\text { Short term stability } \\
(24 \text { h at room temperature) }\end{array}$ & 0.98 & 3.0 \\
$\quad 1.01$ & 20.08 & 1.3 \\
$\quad 19.99$ & & \\
$\begin{array}{l}\text { Autosampler stability } \\
\text { (after } 12 \text { h) }\end{array}$ & 0.96 & 4.4 \\
$\quad 1.02$ & 19.83 & 1.9 \\
20.06 & 0.96 & 4.2 \\
Three freeze-thaw cycles & 19.83 & 2.3 \\
$\quad 1.02$ & & \\
20.02 & 1.07 & 3.9 \\
Long-term stability & & 1.1 \\
\hline days at $\left.-20^{\circ} \mathrm{C}\right)$ & 20.10 & \\
1.02 & & \\
19.98 & & \\
\hline
\end{tabular}

a $n=3$. 
The obtained results indicate that the analyte is stable under any of the storage conditions described above and that no stability related problems would be expected during the routine saliva sample analysis.

\section{Analysis of patient saliva}

The validated method was applied to saliva samples collected from epileptic patients (currently 10 patients are enrolled in the study, age range 18-55 years) under oral chronic VPA therapy. The chromatograms of saliva samples from two patients, one who received $500 \mathrm{mg} \mathrm{day}^{-1}$ and the other who received $800 \mathrm{mg} \mathrm{day}^{-1} \mathrm{VPA}$, collected $2 \mathrm{~h}$ after the last drug intake, are presented in Fig. 2, and the VPA concentrations of 2.17 and 6.74 $\mu \mathrm{g} \mathrm{mL} \mathrm{L}^{-1}$, respectively, were found by interpolation on the calibration curve. Results of the assays of saliva samples of 10 patients ( 5 patients who received $500 \mathrm{mg}^{\text {day }}{ }^{-1} \mathrm{VPA}$ and 5 patients who received $800 \mathrm{mg} \mathrm{day}^{-1} \mathrm{VPA}$ ) were $1.85 \pm 0.23$ and $7.24 \pm 0.53 \mu \mathrm{g} \mathrm{mL}{ }^{-1}$, resp.

a)

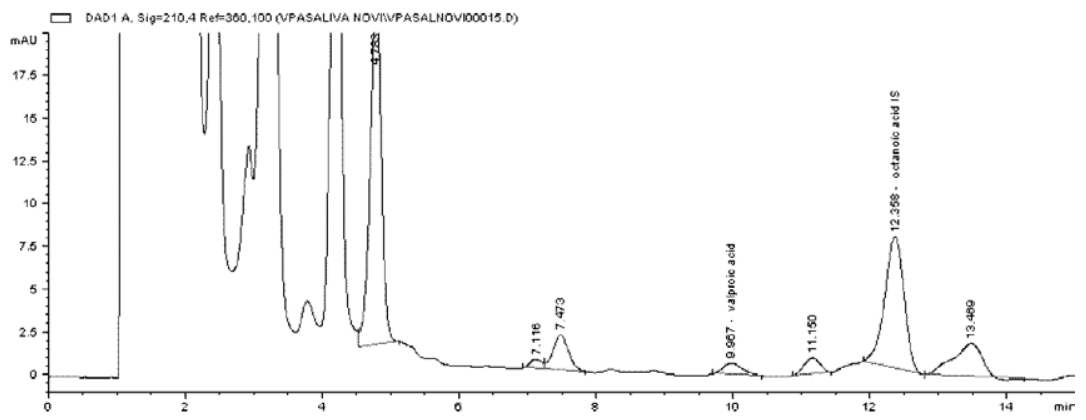

b)

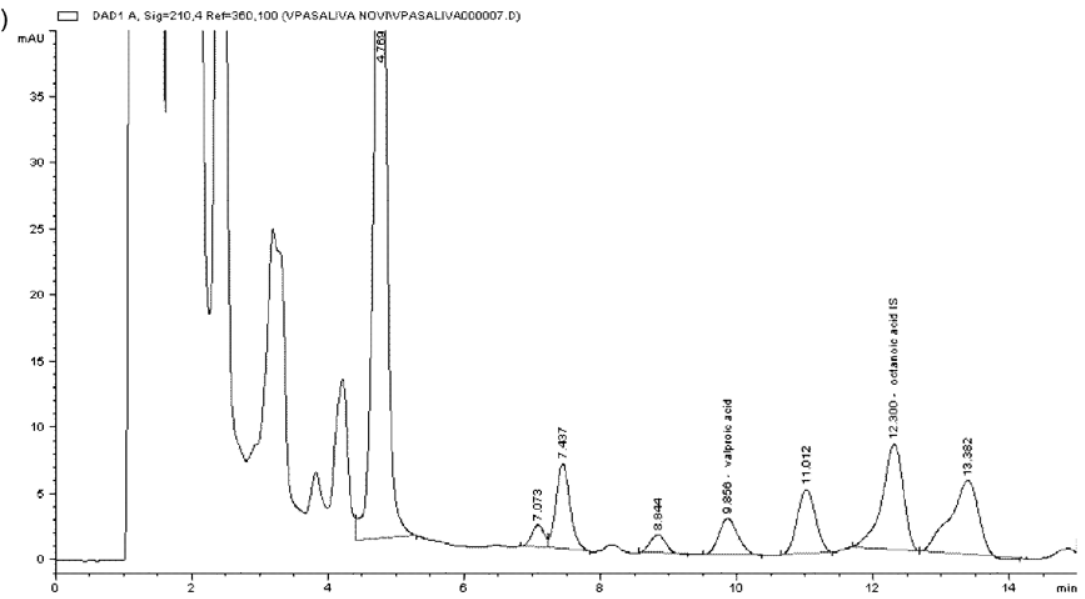

Fig. 2. RP-HPLC chromatograms of saliva samples obtained from a patient treated with a) $500 \mathrm{mg}$ day $^{-1}$ and b) $800 \mathrm{mg} \mathrm{day}^{-1}$ of valproic acid, collected $2 \mathrm{~h}$ after the last drug intake. Unnamed peaks are the endogenous components of saliva. 
The method gives promising results with saliva samples and was shown to be useful for easy therapeutic drug monitoring of valproic acid in epileptic patients after valproic acid oral administration. Additional collection of data is needed in order to confirm this trend.

Having in mind that epileptic patients are often treated with polytherapy, to evaluate the selectivity of the proposed method, saliva samples taken from patients simultaneously treated with carbamazepine, lamotrigine and topiramate (commonly prescribed drugs along with VPA in Macedonia) were analysed. No chromatographic interference was observed in the retention times of VPA and IS, hence the method could be used even when other antiepileptic drugs were co-administered.

\section{CONCLUSIONS}

A simple, sensitive and reliable RP HPLC-UV method has been developed for determination of valproic acid in human saliva after solid-phase extraction. The method allows determination of valproic acid at low concentration without prior derivatization. Validation data demonstrate that the proposed bioanalytical method is selective, sensitive, precise and accurate and therefore suitable for determination of saliva concentrations of this antiepileptic drug. Saliva levels reflect the free and therefore the pharmacologically active fraction of valproic acid and may be determined after collecting samples in a convenient and noninvasive way. Further investigations are needed in order to determine the correlation between saliva and plasma concentrations of valproic acid and to assess the feasibility of salivary valproic acid determination for routine therapeutic drug monitoring.

\section{REFERENCES}

1. P. Loiseau, Rational use of valproate: Indications and drug regimen in epilepsy, Epilepsy 25 (1984) 65-72; DOI: 10.1111/j.1528-1157.1984.tb05641.x.

2. O. Dulac, D. Steru, E. Rey and M. Arthius, Sodium valproate monotherapy in childhood epilepsy, Brain Dev. 8 (1986) 47-52.

3. D. C. Lagacea, W. T. O'Brienb, N. Gurvichb, M. W. Nachtigala and P. S. Klein, Valproic acid: How it works. Or not, Clin. Neurosci. Res. 4 (2004) 215-225; DOI: 10.1016/j.cnr.2004.09.013.

4. P. Wal, B. Kumar, A. Bhandari, A. K. Rai and A. Wal, Bioanalytical method development - Determination of drugs in biological fluids, J. Pharm. Sci. Tech. 2 (2010) 333-347.

5. S. I. Johannessen, Therapeutic Drug Monitoring of Antiepileptic Drugs, in Drug Monitoring and Clinical Chemistry (Ed. G. Hempel) in Elsevier, Amsterdan 2004, in (Ed. R. M. Smith) Handbook of Analytical Separation. Vol. 5, pp. 221-253; DOI: 10.1016/S1567-7192(04)80010-X.

6. P. N. Patsalos, D. J. Berry, B. F. D. Bourgeois, J. C. Cloyd, T. A. Glauser, S. I. Johannessen, I. E. Leppik, T. Tomson and E. P. Patsalos, Antiepileptic drugs - best practice guidelines for therapeutic drug monitoring: A position paper by the subcommission on the therapeutic drug monitoring, ILAE Commission on Therapeutic Strategies, Epilepsia (2008) 1-38; DOI: 10.1111/j.1528-1167.2008.01561.x.

7. S. J. Soldin, Free drug measurement, Arch. Pathol. Lab. Med. 123 (1999) 822-823.

8. H. Liu and M. R. Delgado, Therapeutic drug concentration monitoring using saliva samples, Clin. Pharmacokin. 36 (1999) 453-470; DOI: 10.2165/00003088-199936060-00006. 
J. Tonic-Ribarska et al.: Development and validation of a bioanalytical LC-UV method with solid-phase extraction for determination of valproic acid in saliva, Acta Pharm. 62 (2012) 211-220.

9. H. S. Chung, T. L. Seung and L. Soo-Youn, Evaluation of Viva-E drug testing system, Korean J. Lab. Med. 27 (2007) 330-337; DOI: 10.3343/kjlm.2007.27.5.330.

10. R. L. Dills and D. D. Shen, Methods to reduce background interferences in electron-capture gas chromathographic analysis of valproic acid and its unsaturated metabolites after derivatization with pentafluorobenzyl bromide, J. Chromatogr. B Biomed. Appl. 690 (1997) 139-152; DOI: 10.1016/ S0378-4347(96)00405-7.

11. S. Rompotis, M. Parissi-Poulou, E. Gikas, M. Kazanis, A. Vavayannis and I. Panderi, Determination of valproic acid in human plasma by HPLC with fluorescence detection, J. Liq. Chromatogr. 25 (2002) 2833-2847; DOI: 10.1081/JLC-120014953.

12. H. Amini, M. Javan and A. Ahmadiani, Development and validation of a sensitive assay of valproic acid in human plasma by high-performance liquid chromatography without prior derivatization, J. Chromatogr. B 830 (2006) 368-371; DOI: 10.1016/j.jchromb.2005.11.028.

13. D. S. Jain, G. Subbaiah, M. Sanyal and P. Shrivastav, A high through and selective method for the estimation of valproic acid an antiepileptic drug in human plasma by tandem LC-MS/MS, Talanta 72 (2007) 80-88.

14. Guideline on validation of bioanalytical methods, European Medicines Agency, Committee for Medicinal Products for Human Use (CHMP), London 2009; http://www.ema.europa.eu/docs/ en_GB/document_library/Scientific_guideline/2009/12/WC500018062.pdf.

15. M. Krogh, K. Johansen, F. Tonnesen and K. E. Rasmussen, Solid-phase microextraction for the determination of the free concentration of valproic acid in human plasma by capillary gas chromatography, J. Chromatogr. B 673 (1995) 299-305; DOI: 10.1016/03784347(95)00273-8.

\author{
$S A \check{Z} E T A K$
}

\title{
Razvoj i validacija bioanalitičke LC-UV metode s ekstrakcijom na čvrstoj fazi za određivanje valproične kiseline u slini
}

\author{
JASMINA TONIC-RIBARSKA, ARLINDA HAXHIU, ZORAN STERJEV, GORDANA KITEVA, \\ LjUBICA SUTURKOVA i SUZANA TRAJKOVIC-JOLEVSKA
}

U radu je opisana i validirana bioanalitička HPLC metoda s UV detekcijom za određivanje antiepileptika valproične kiseline u slini čovjeka. Zbog sve većeg interesa za praćenje koncentracije slobodnog lijeka slina predstavlja alternativni matriks za praćenje antiepileptika. Predložena metoda u pripremi uzorka uključuje ekstrakciju na čvrstoj fazi. Dobiven je vrlo dobar srednji analitički povrat od 99,4 \% i 97,9 \% za valproičnu kiselinu, odnosno IS. Kalibracijska funkcija za valproičnu kiselinu bila je linearna u koncentracijskom području od $1,0-50,0 \mu \mathrm{g} \mathrm{mL}-1\left(R^{2}=0,9989\right)$. Preciznost i točnost procijenjene unutar jednog i više mjernih dana dale su RSD niže od 7,3 i 2,2 \%, te vrijednosti za točnost iznad 96,8, odnosno 97,5\%. Opisana metoda je dovoljno osjetljiva, precizna i točna, osigurava linearni odgovor te je pogodna za analizu valproične kiseline $u$ slini.

Ključne riječi: valproična kiselina, slina, ekstrakcija na čvrstoj fazi, visokotlačna tekućinska kromatografija s visokom učinkovitosti, validacija

Institute of Applied Chemistry and Pharmaceutical Analysis, Faculty of Pharmacy, University »Ss Cyril and Methodius", Skopje, Macedonia

Department of Pharmacy, Medical Sciences Faculty, State University of Tetova, Tetovo, Macedonia 